\title{
Sea level changes in Fiji
}

\begin{abstract}
The Fiji Islands are occasionally cursed by destructive cyclones. This was the case of Cyclone Winston on February 16, 2016. Sea level changes are quite another thing. We undertook a detailed field investigation at 12 different sites in the Fiji Islands, and were able to demonstrate that sea level is not at all in a rising mode today. On the contrary, sea level has remained quite stable over the last 50-70 years as indicated by microatolls and coastal morphology at different sites in different dynamic settings. The good thing with microatolls is that they do not lie.
\end{abstract}

Keywords: Sea level changes, Coastal morphology, Microatolls, Tide-gauges, Coastal erosion, Fiji
Volume 6 Issue 5 - 2017

\section{Nils Axel Morner,' Pamela Matlack Klei \\ 'Paleogeophysics Geodynamics Sweden}

${ }^{2}$ Portuguese Sea Level Project Sweden

Correspondence: AA Ortega-Salas, Unidad Académica Mazatlán, Instituto de Ciencias del Marry Limnología, UNAM. Calzada Joel M, México,Email ortsal@ola.icml.unam.mx

Received: November 18, 2017 | Published: December II, 2017

\section{Introduction}

At the COP23 meeting in Bonn (November, 2017) it was officially claimed that "nowhere is climate change more evident than on this small island-state in the Pacific" and that "sea is rising so fast that it is flushing into the gardens of the people". Both these statements violate existing facts. As to the climate statement, the Fiji Islands occasionally are struck by destructive weather events. This was the case on February 16, 2016, when Cyclone Winston struck the islands. Shores, houses and habitation grounds were seriously destroyed. This was a weather event, however, and has nothing to do with sea level changes as such. As to the claim that sea is rising fast, this is not founded in observational facts; rather is it a misunderstanding of coastal deformations from cyclone Winston.

In this paper we will show that sea level has remained quite stable during the last 50-70 years, after a $10 \mathrm{~cm}$ lowering 60-70 years ago. The sea level stability is evident from a number of corals at different sites, which had reached the minimum depth of $40 \mathrm{~cm}$ below lowwater level, and therefore were forced to grow laterally.

\section{Material and methods}

We undertook a detailed sea level investigation at a few sites on Vitu Levi (the main island) and at 10 sites in the Yasawa Islands in March, 2017. Much attention was paid to the fine structure of coastal morphology. The high-tide level is very sharply identifiable in the field; bedrock notches and under-cut structures, rock-cut platforms, biological high-tide markers, sediment deposits and stratigraphy. Elevation was measured with a high-precision instrument (Kern GK 1). Samples were collected for C14-dating; 17 samples were AMSdated at the Uppsala Laboratory.

\section{Results}

\section{Tide-Gauge stations}

We analysed the Lautoka and Suva tide-gauge stations on the Island of Vitu Levu, ${ }^{1}$ and concluded that none of them were actually trustworthy because the recording instruments' position, attached to heavy harbour constructions resting on soft sediments, which are susceptible to serious compaction.

\section{Coastal erosion}

The coastal erosion along the shores of the Fiji islands is not serious, but occurs sporadically. We analysed a number of cases ${ }^{2}$ and were able to show that the erosion had nothing to do with sea level rise, but were the products of human mistakes in shore managements.

\section{Sea Level changes}

No other investigation had previously presented any data on sea level changes during the last 500 years. We established a 3-part sequence: ${ }^{3,4}(1)$ a $+70 \mathrm{~cm}$ high during the $16^{\text {th }}$ and $17^{\text {th }}$ centuries, (2) a $-50 \mathrm{~cm}$ low during the $18^{\text {th }}$ century, and (3) a virtually stable level at $\pm 0.0 \mathrm{~cm}$ during the $19^{\text {th }}, 20^{\text {th }}$ and early $21^{\text {st }}$ centuries (Figure 1 ). Level 3 can be subdivided in a $+30 \mathrm{~cm}$ high in the early $19^{\text {th }}$ century, a long $+10 \mathrm{~cm}$ level up to about 1950-1960, when sea level fell 10-20 cm, killing corals close to their minimum depth below low tide level, and a stable level for the last 50-70 years. We have dated several dead centers of corals at younger than 1950. Coral tops at a minimum depth of $40 \mathrm{~cm}$ below low-tide level were forced to grow laterally. This was found and dated at several places. A coral at $45 \mathrm{~cm}$ depth below lowtide level continued to grow all over its surface. This indicates how very delicate the minimum depth of vertical coral growth is. This is why the forced growth into "microatolls" is a direct proof of stable sea level conditions over the last 50-70 years.

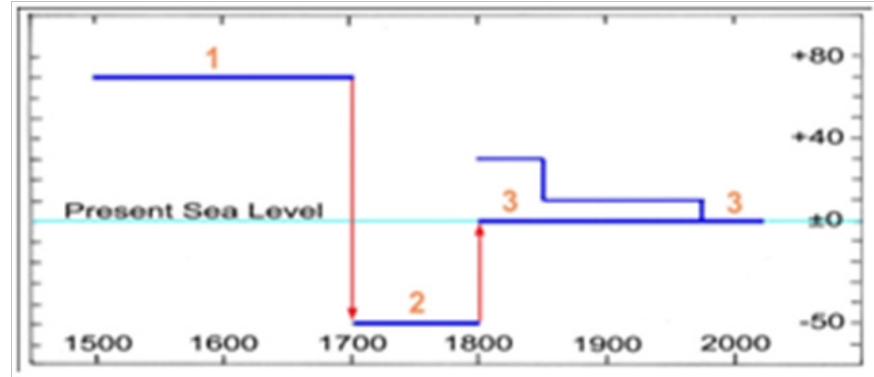

Figure I Sea level changes during the last 500 years in the Fiji region. ${ }^{3-5}$

Figure 2: A coral that died due to sea a level lowering after 1950 (the dead centre dated at $<1950$ ) now $40 \mathrm{~cm}$ below low-tide level. Today, the living corals around the edges cannot grow upwards because of the depth and are forced to grow laterally into a microatoll. This is observed at several places in the Yasawa Islands. A coral with its surface only $5 \mathrm{~cm}$ lower is growing into a normal round coral. This indicates how very sensitive corals are to the minimum depth below low-tide level. It also implies that sea level must have remained quite stable over the last 50-70 years. ${ }^{3,4}$

\section{Discussion}

The mixing of effects from the Cyclone Winston weather phenomenon and the dynamics of sea level changes by the COP23 officials provides an incorrect and false picture of what is really going 
on with the regional eustatic sea level. ${ }^{3,4}$ We pointed this out in an open letter ${ }^{5}$ to the Prime Minister of Fiji, who was the acting President of COPP23 in Bonn.

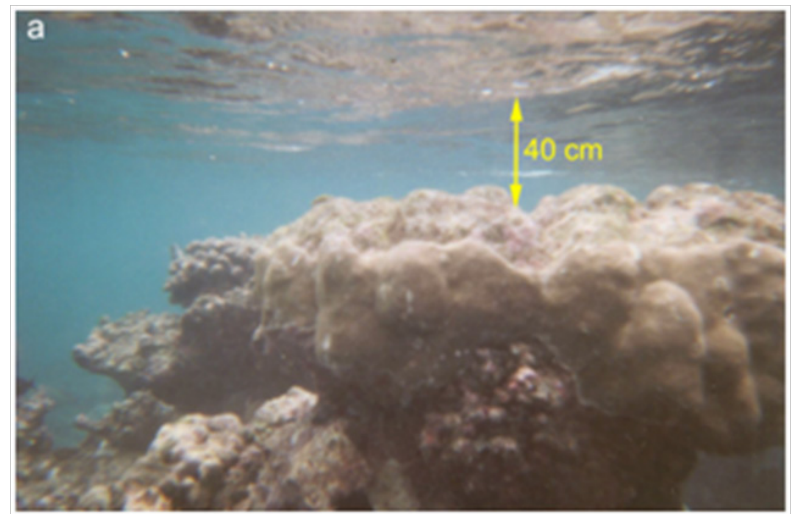

Figure $2 \mathrm{~A}$ coral that died due to sea a level lowering after 1950.

Shore morphology and forced coral growth are such excellent means of defining sea level changes that they have the weight of proving the case; i.e. no present sea level rise in the Fiji region and strictly stable sea level during the last 50-70 years.

\section{Acknowledgments}

None.

\section{Conflicts of Interest}

None.

\section{References}

1. Mörner N-A, Matlack-Klein P. The Fiji tide-gauge stations. International Journal of Geoscience. 2017;8:536-544

2. Mörner N-A, Matlack-Klein P. Coastal erosion in the Yasawa Islands, Fiji. Nature Science. 2017;9(5):136-142.

3. Mörner N-A, Matlack-Klein P. Our Oceans-Our Future: New evidence-based records from the Fiji Islands for the last 500 years indicating rotational eustasy and absence of a present rise in sea level. International Journal of Earth \& Environmental Sciences. 2017;2:137.

4. Mörner N-A, Matlack-Klein, P. New records of sea level changes in the Fiji Islands. Oceanography \& Fishery Open Access Journal, in press. 2017.

5. Mörner, N-A, Matlack-Klein, P. Open Letter to Honorable Prime Miniter of Fiji and the President of COP23, Frank Bainimarama. Sent to the COP23 office on November 12. Tallbloke's Talkshop. 2017. 